\title{
THE MEASUREMENT OF PROFESSIONAL COMPETENCY TO SCHOOL TEACHER'S ACHIEVEMENT AT PGRI UNIVERSITY YOGYAKARTA LABORATORY
}

\section{Eko Wahyunanto Prihono ${ }^{\bowtie}$, dan Supahar Supahar}

Post Graduate Program, Yogyakarta State University

\begin{tabular}{|c|c|}
\hline Info Artikel & Abstract \\
\hline $\begin{array}{l}\text { Sejarah Artikel: } \\
\text { Diterima: } 14 \text { Mar } 2018 \\
\text { Direvisi : } 21 \text { Mar } 2018 \\
\text { Dipublikasikan: Jun } 2018 \\
\text { Keywords: } \\
\text { Measurement, Professional } \\
\text { Competence, Teacher's } \\
\text { achievement }\end{array}$ & $\begin{array}{l}\text { This research aimed: (1) to measure the school teacher's achievement at PGRI University of Yogyakarta } \\
\text { laboratory, and (2) to describe the measurement results of school teacher's achievement at PGRI } \\
\text { University of Yogyakarta laboratory in terms of teacher professionalism competence. This research was } \\
\text { a quantitative descriptive. Populations were all high class teachers and Elementary School headmasters. } \\
\text { Cluster random sampling technique is used as sampling technique. Data collection techniques used tests } \\
\text { and questionnaires. Validity on professional competence instruments used the content and construct } \\
\text { valdities. The estimation of instrument reliability used cronbanch alpha. The results showed that: (1) the } \\
\text { average achievement score of teacher was } 71.00 \text { from O-100 range score and (2) there were } 4 \\
\text { subdistricts and } 18 \text { elementary schools with low category in teacher's achievement assesment at PGRI } \\
\text { University Yogyakarta. }\end{array}$ \\
\hline
\end{tabular}

\begin{abstract}
Abstrak
Penelitian ini bertujuan: (1) untuk mengukur prestasi kerja guru sekolah laboratorium Universitas PGRI Yogyakarta, dan (2) mendeskripsikan hasil pengukuran prestasi kerja guru sekolah laboratorium Universitas PGRI Yogyakarta ditinjau dari kompetensi profesionalisme guru. Penelitian ini merupakan penelitian deskriptif kuantitatif. Populasi dalam penelitian ini adalah seluruh guru kelas tinggi dan kepala sekolah jenjang sekolah dasar. Teknik pengambilan sampel menggunakan menggunakan teknik cluster random sampling. Teknik pengumpulan data dalam penelitian menggunakan tes dan angket. Validitas pada instrumen kompetensi profesional menggunakan validitas isi dan valditas konstruk. Adapun estimasi reliabilitas instrumen dalam penelitian ini menggunakan cronbanch alpha. Hasil penelitian menunjukkan bahwa: (1) pencapaian rerata nilai prestasi kerja guru secara keseluruhan sebesar 71,00 dari rentang skor 0-100 dan (2) terdapat 4 kecamatan dan 18 Sekolah Dasar dengan kategori rendah dalam penilaian prestasi kerja guru sekolah laboratorium Universitas PGRI Yogyakarta.
\end{abstract}

(c) 2018 Universitas Muria Kudus

\begin{tabular}{lr}
\hline Alamat korespondensi: & p-ISSN 2087-9385 \\
Program Studi Pendidikan Guru Sekolah Dasar & e-ISSN 2528-696X \\
Fakultas Keguruan dan Ilmu Pendidikan Universitas Muria Kudus & \\
Kampus UMK Gondangmanis, Bae Kudus Gd. L. 1t I PO. BOX 53 & \\
Kudus & \\
Tlp (0291) 438229 ex.147 Fax. (0291) 437198 & \\
E-mail: ekowahvunantoprihono@gmail.com &
\end{tabular}




\section{BACKGROUND}

Regional Education Balance (REB) in 2016 released the number of elementary school teachers for Yogyakarta Special Province (DIY) around 17,762 teachers. The achievement of teacher competence test's average results in 2016 for DIY was 67.02. The teacher competence test's average results in 2016 is nationally the highest achievement compared to other provinces. The teacher competence test's results from each level, namely: for elementary school level of 66.36; junior high school of 68.92; senior high school 73.78 and for vocational high school level of 66 .

Overall the average of teacher competence test results from each level is good, this is due to the achievement is above the national average score around 56, 69. In addition, there is plan that teachers in the position is planned to be certified gradually until 2021 (Kartowagiran, Soenarto \& Triyono: 2011). It is indicates that the government has actually made a real effort in improving the quality of education through certification for teachers. However, this is also became a particular concern to the government when the teachers who have certified has decreased achievement and does not meet certification standards anymore.

The decrease of teachers' achievement can be caused by several things such as the increasing number of tasks that teachers have to do, the lack of awards or the welfare of the teachers, and the low motivation of the leader to the teacher. Barnawi \& Mohammad Arifin (2014: 15-24) mentions at least 5 (five) job descriptions of teachers such as: 1) Planning lessons, 2) Implement learning, 3) Assess learning outcomes, 4) guide and train students, 5) Carry out additional structural and special tasks. Another matter delivered by Podgursky \& Springer (2007), an appropriate appreciation of teacher skills and knowledge will have a good effect on the learning process.

Suyadi Prawirosentono (1999) states that work achievement is the work that can be achieved by a person or group of people within an organization, in accordance with the authority and responsibility of each, in order to achieve the objectives of the organization concerned legally, not violating the law and appropriate with morals or ethics. Dessler (1997), states work performance is a comparison between the actual work with the established standard of work. While Fitzpatrick \& Morrison in Johnson, Penny \& Gordon (2009: 2) states that performance is an attitude aimed at modifying the environment in a prescribed manner.
Performance is defined as a record of the results generated on a particular job function or activity over a given period of time. Teacher performance in school is strongly influenced by motivation. Teacher performance can be well mapped through training programs for teachers at school. In addition, teachers will gain increased motivation and confidence (Inayatullah, A. \& Jehangir, P.).

Cai and Lin (2006) states that teacher performance dimension is categorized in several ways such as demographic of morality shows the identity and support in organization, have a working dedication, assistance and cooperation that refers to teacher behavior such as help the colleagues, have a good relationships with parents, teach effectively, interact with fellow teachers or students inside or outside the classroom.

Based on the description, it can be concluded that the teachers' performance is the results achievement of learning activities that have been done inside and outside the classroom. In addition, teacher work performance can be reviewed from the ability or competence such as knowledge, skills and good working relationships with leaders and colleagues.

The achievement of work achievement is widely inseparable from the Law of Teachers and Lecturers Number 14, 2005 which states that teachers must have academic qualifications, competence, educator certificate, physical and spiritual health, and have the ability to realize the goals of national education. Academic qualifications for teachers are made through: 1) Formal Education, and 2) Feasibility and Equity Test. The academic qualification refers to the minimum education of diploma four or bachelor in each of the formal education field, the study program in accordance with the subjects taught and obtained from an accredited study program.

Currently, the qualifications of teachers in DIY for each level are mostly graduates of diploma four or bachelor. This can be seen from the qualifications of each level, namely: for primary and junior high school for 88.7; for senior high school level of 96,4; and for vocational high school level 94.4 (NPD: 2016).

The Teachers and Lecturers Law states that the academic qualifications required to be appointed as teachers in specific fields indispensable but not yet developed in universities can be obtained through the feasibility and equity test. While the academic qualification through the feasibility and equity test for someone who has expertise without a diploma conducted by universities authorized to 
implement it. In addition to teachers must have academic qualifications, teachers must have four teacher competencies. The four competencies that must be owned by teachers such as pedagogic, personality, social, and professional competence.

Most teachers in DIY are academically qualified of diploma four or bachelor. This indicates that government efforts to require teachers to have academic qualifications have been met. Referring to data of Regional Education Balance in 2016, there were still three levels in DIY which achievement of teacher competency test average still in low category. The low achievement of teacher competency test can indicate the low of teachers'competence.

One of the teacher competencies must be owned by teacher is professional competence. Professional competence is the ability of teachers in mastering knowledge of science, technology, and / or art and culture that they received. Government Regulation No. 74 of 2008, specifically describes professional competence, consisting of: 1) mastery of subject matter in a broad and in-depth in accordance with standard content of educational unit program, subject, and/or subject group to be addressed; and 2) relevant scientific, technological or artistic disciplinary concepts and methods, which are conceptually shaded or coherent with the educational unit, subjects, and / or subject groups to be taught.

Virtanen, Niemi \& Nevgi (2017) states that the professional competence of teachers to give a positive influence in the learning process for teachers and students. This can be done through several things including: starting a lifelong professional growth process, developing professional self-esteem, professional selfidentification (eg teachers acting as teachers) and strengthening the teaching view by creating a new perspective as an educator profession. This shows that professional competence of teachers is needed in the learning process.

The low level of teacher competency test can be seen through the achievement measurement result achieved by the teacher. Fatimah \& Mahmudah (2017) describes the performance efficiency measurement to be important because it is closely related to the quality of education. Prasetya (2012) describes that the measurement is comparing something measured by the appropriate measuring instrument and then the result of the measurement is written in a number or number. The measurement is closely related to the score system or can be called by assesment.
Mardapi (2012) defines that assessment as an activity of interpreting or describing the results of measurement. Measurements in this research focused on assessing teacher personally. Therefore, it is necessary to make a deep diagnosis of the ability of each teacher, in order to provide a fair assessment results. In addition, Maslach \& Jackson (1981) state the personal judgments on certain basic job dimensions is part of the job diagnosis survey. While Wren in Supahar, Rosana, Ramadani, \& Dewi (2017) defines performance assesment as an assessment that emphasizes the aspect of the skills demonstrated by the learner and not the assessment whereby the learner only answers or selects answers from a range of possible answers.

Based on the description of the assessment, it can be concluded that the ability of someone with another person is different. One effort that can be done to determine the differences in a person can be done by using a reference to select and know the differences in a group. Therefore, researcher make measurements on teacher performance in terms of professional teacher's competence.

\section{METHOD}

This research is conducted by using quantitative descriptive method. It is conducted to determine the achievement elements that existed in teacher, especially on teacher's professional competence. In addition, this reserach is conducted also to explore the ability or professional competence owned by the teachers. Quantitative approach method is used in this research due to researcher want to dig and collect data/ information as much as possible about teacher work performance through the professional competence assesment.

This research is conducted in Bantul Regency, Yogyakarta Special Region. Elementary schools both state and private as places to get the data. Populations were all high class teachers and headmasters from 52 Elementary Schools in Bantul Regency. Then, the researcher took the sample from each sub dsitrict in Bantul Regency used cluster random sampling technique. Waksberg (1978) states that cluster random sampling is used in a population in certain groups. This technique is done through the grouping of each of elementary school in Bantul district. There were 144 samples for high class teachers and 48 headmasters.

Tests and non-tests assesments were used to collect the data on teacher's achievement. Objective multiple choice test with the scale of politomus is used by researcher as test 
instrument, ie each test answer option has a different score. The highest score was 4 (four) and the lowest score was 1 (one). Preparation of teacher test instruments used the grain response politomus model with nominal characteristics.

Retnawati (2014) states that the nominal grain response model can be applied to items that have alternative (optional) unordered answers and the various levels of measured capabilities. While the non-test instrument used a questionnaire with a summative rating scale. However, the researcher developed the instrument in the form of a statement and the respondent only gives a checklist for the statement that is in accordance with the assessed object (teacher), then the researcher gives scores on the respondents (headmaster).

Professional competency instrument is a measuring tool that will be used to assess the teacher performance. Therefore, the instrument used by the researcher were valid and reliable instrument. Kartowagiran (2012) states that one of the requirements to obtain a good instrument is the fulfillment of validity and good reliability. This is done so that the instrument is able to measure accurately when used to measure teacher work performance in different places. Furthermore Kartowagiran \& Maddini (2015) states that testing the validity of an instrument can utilize the content validity through expert judgment. While the reliability estimation can be done through Alpha Cronbach used GENOVA software.

The instruments were expected to be able to measure the teacher performance well. So that the researcher can prove the validity of the instrument used. Validity on professional competency instruments used content and construct valdities. Content validity is conducted through expert agreement, then the result of expert agreement is calculated used Aiken's V formula which was one of the statistics to show the validity of item contents. Azwar in Yadiannur \& Supahar (2017) and Retnawati (2015) outlines Aiken's V formula on content validity.

$$
\mathrm{eV}=\sum \mathrm{s} /[\mathrm{n}(\mathrm{c}-1)]
$$

Kartowagiran (2008), states that construct validity test can be done in two ways, namely exploratory factor analysis and confirmatory factor analysis. While the validity of the construct used the exploratory factor analysis (EFA) which aims to investigate the factors contained in the points of observation. Azwar (2015) states that exploratory factor analysis is exploring empirical data to find and detect characteristics and relationships among variables without specifying models in the data. The grainability feasibility test is conducted used exploratory factor analysis (EFA). The criteria met in this analysis are presented in Table 1.

Table 1. Criteria in EFA

\begin{tabular}{lc}
\hline \multicolumn{1}{c}{ Criteria } & Score \\
\hline Keyser Mayer Oikin (KMO) score & $>0.5$ \\
Barlett's Test of Sphericity significant & $<0.05$ \\
score & $>0.5$ \\
Antiimage corelation & $>1.0$ \\
$\begin{array}{l}\text { Eigenvalue score on Total Variances } \\
\text { Explained }\end{array}$ & $>0.4$ \\
\hline
\end{tabular}

Supahar, Rosana, Ramadani, \& Dewi (2017) states that instruments are said to be consistent when the instrument is performed from time to time but has the same score. Reliability is one of the criteria in an instrument development. If the instumen reliability is high, then an instrument is very good when used in measurement. The estimation of instrument reliability used cronbach alpha. Brown (2002) suggests that cronbach alpha can provide an internal consistency estimate in the test, thus indicating the consistency of the instrument over time. Feldt (1980) and Retnawati (2015) briefly elaborate the formula cronbach alpha.

$$
r_{11}=\left[\frac{k}{k-1}\right]\left[1-\frac{\sum \sigma_{b}^{2}}{V_{t}^{2}}\right]
$$

Data analysis technique used quantitative descriptive analysis. Quantitative data analysis is conducted by obtaining the mean and standard deviation which then presented in the form of tables and bar charts and pie. Analysis quantitatively in this research will also be used to see the extent of achievement the work of teachers from each competency, in whole, each sub-district, or each school. The criteria determination is done according to Table 2.

Table 2. The average interval convertion on teacher's achievement

\begin{tabular}{llcl}
\hline No. & Interval score & Score & Category \\
\hline 1. & $\mathrm{Y} \geq \overline{\mathrm{Y}}+1 . \mathrm{SBy}$ & $85<X \leq 100$ & Very high \\
2. & $\overline{\mathrm{Y}}+1 . \mathrm{SBy}>\mathrm{Y} \geq \overline{\mathrm{Y}}$ & $70<X \leq 85$ & High \\
3. & $\overline{\mathrm{Y}}>\mathrm{Y} \geq \overline{\mathrm{Y}}-1 . \mathrm{SBy}$ & $55<X \leq 70$ & Low \\
4. & $\mathrm{Y}<\overline{\mathrm{Y}}-1 . \mathrm{SBy}$ & $X \leq 55$ & Very low \\
\hline
\end{tabular}

Notes :

$\overline{\mathrm{Y}} \quad=$ average score

SBy = standard deviation of the total score of teachers tested

$\mathrm{Y}=$ teacher's score

(Mardapi: 2012) 


\section{RESULT AND DISCUSSION \\ Result}

Assessment of teacher achievement used test and non test instruments. Validity of professional competency instruments used content and construct valdities. The content validity is performed by the expert and the experts score is used to calculate the magnitude of the content coefficient of Aiken's $\mathrm{V}$ content. The teacher test instruments consists of 40 items and the questionnaire consists of 15 items of statement. The results of the validity analysis of test and non test instrument contents mostly indicate that the magnitude of Aiken's coefficient $\mathrm{V} \geq 0.80$ on each item. It shows that each item has very high validity criteria.

The proof of construct validity in professional competency instruments used exploratory factor analysis (EFA) which aims to investigate factors contained in the points of observation. The result of construct validity analysis used EFA on test instrument showed that the sufficiency of sample is reviewed by Kaiser-Meyer-Olkin Measure of Sampling Adequacy (KMO) of 0.648 which is greater than $0.5(>0,5)$. The score of loading factor on each test item through EFA has met the specified criteria that is more than $0.4(>0.4)$. So all the test items were valid.

The result of construct validity analysis used EFA on non test instrument showed that sample adequacy based on Kaiser-Meyer-Olkin Measure of Sampling Adequacy (KMO) of 0.875 is greater than 0.5 . The full results are presented in Table 3.

Table 3. KMO and Bartlet Headmaster Instrument

\begin{tabular}{rcr}
\hline \multicolumn{2}{r}{$\begin{array}{r}\text { Kaiser-Meyer-Olkin Measure of } \\
\text { Sampling Adequacy. }\end{array}$} &, 875 \\
\hline $\begin{array}{r}\text { Bartlett's Test } \\
\text { of Sphericity }\end{array}$ & Approx. Chi-Square & 6731,057 \\
\cline { 2 - 3 } & Df & 1128 \\
\cline { 2 - 3 } & Sig. & 0,000 \\
\hline
\end{tabular}

Based on the analysis of the adequacy of the sample, then the non test instrument is feasible to be used. In addition, all items in this instrument can be further analyzed through factor analysis with extraction and rotation methods used varimax. The results of the Rotated Component Matrix Results analysis are presented in Table 4

Table 4. Rotated Component Matrix Result

\begin{tabular}{|c|c|c|c|c|c|c|c|c|c|c|c|c|c|c|c|}
\hline \multirow{2}{*}{ Component } & \multicolumn{15}{|c|}{ Number of Items } \\
\hline & 1 & 2 & 3 & 4 & 5 & 6 & 7 & 8 & 9 & 10 & 11 & 12 & 13 & 14 & 15 \\
\hline 1 & 0,44 & 0,69 & 0,82 & 0,48 & 0,75 & & 0,56 & & 0,60 & & 0,66 & & 0,63 & 0,43 & \\
\hline 2 & 0,48 & & & & & & & & & & & & & & \\
\hline 3 & & & & & & 0,41 & 0,46 & 0,75 & 0,47 & 0,57 & & & & & \\
\hline 4 & & & & & & & & & & & & 0,78 & & & \\
\hline 5 & & & & & & 0,65 & & & & & & & & & \\
\hline 6 & & & & & & & & & & & & & 0,42 & 0,73 & 0,79 \\
\hline
\end{tabular}

Based on Table 4., it can be seen that loading factor's score in each statement has met the specified criteria that is more than $0.4(>0.4)$. So, all the questionnaire statements were valid and fit to be used to assess the work performance of school teachers at University of PGRI Yogyakarta laboratory.

The number of items on the test instrument of teacher's professional competence were 40 points. Estimated reliability of professional competency instruments used the Alpha formula from Cronbanch. The results of reliability estimation on the instrument of professional competency test of 0.8492 . While the number of statements used on the questionnaire were 15 items. The result of reliability estimation used Alpha formula from Cronbanch for non test instrument equal to 0.8377 . The overall of teacher achievement assesment as a whole in terms of professional competence showed a good achievement average. This can be seen in Table 5 .

Table 5. Overall average 


\begin{tabular}{lccccc}
\hline & N & Min & Max & Mean & $\begin{array}{c}\text { Std. } \\
\text { Deviation }\end{array}$ \\
\hline $\begin{array}{l}\text { Profesional } \\
\text { competence }\end{array}$ & 144 & 40,00 & 89,00 & 71,00 & 12,30 \\
$\begin{array}{l}\text { Valid N } \\
\text { (listwise) }\end{array}$ & 144 & & & & \\
\hline
\end{tabular}

Based on Table 5. the results showed the overall achievement of teachers in the high category with an average achievement of 71.00 . The study involved 11 districts in Bantul District. Therefore, the researcher also present the results of the submissions from all the sub-districts involved. While the results of the achievement of 11 districts, presented in Figure 1.

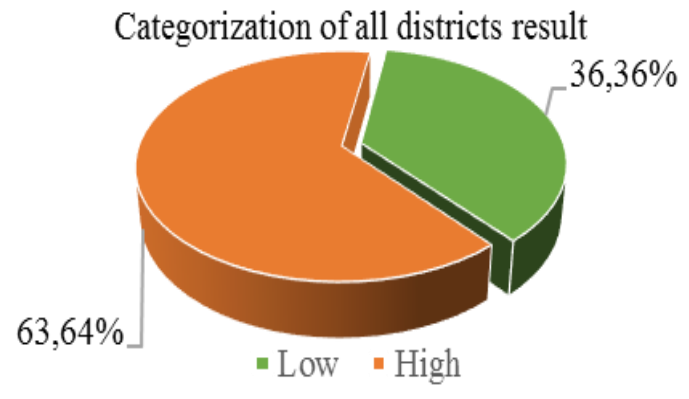

Figure 1. Categorization of all districts result

Based on Figure 1, showed that there were $36.36 \%$ of the 11 districts included in the low category. In detail, the average achievement of each sub district is presented in Figure 2.

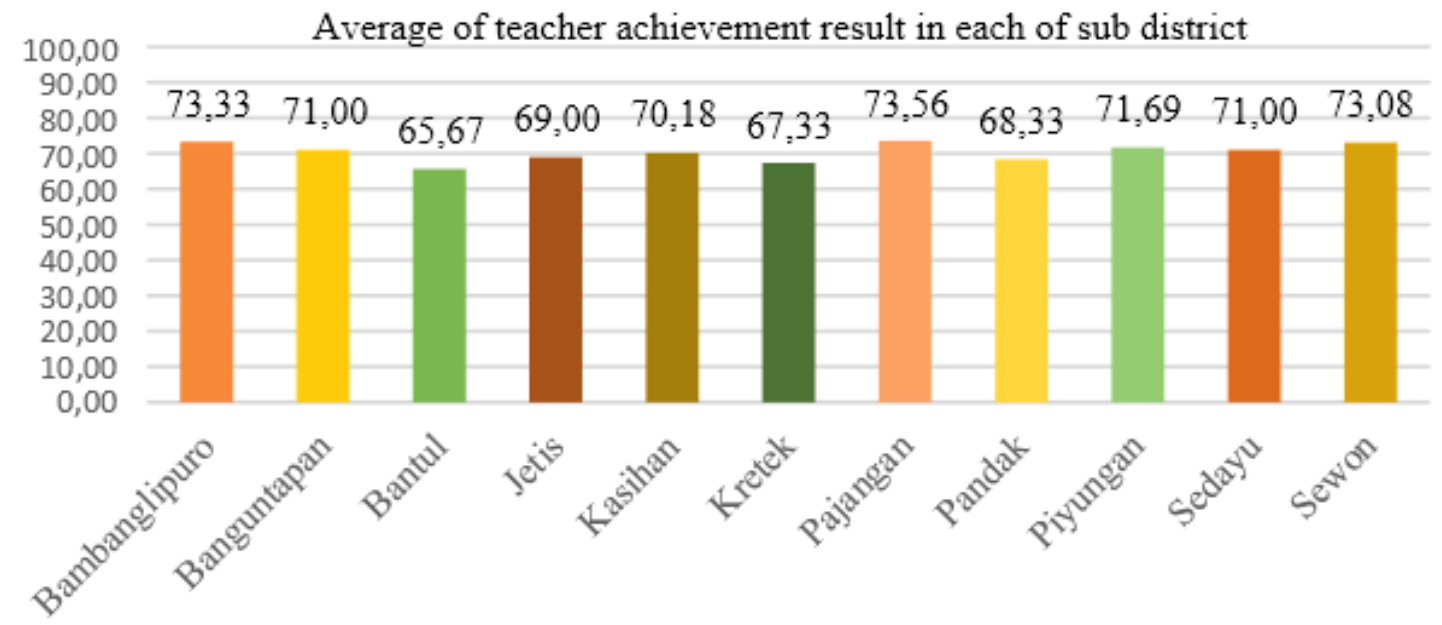

Figure 2. Average of teacher achievement result in each of sub district

Based on Figure 2., it showed that achievement of average achievement of teacher achievement from 4 (four) sub-districts is still low with score score $<70,00(<70,0)$. The four districts, including: Bantul, Jetis, Kretek, and Pandak districts. There were 48 primary schools both public and private used in this research . The categorization of the whole school assessment is presented in Figure 3.

Based on Figure 3, showed the results of the assessment around $62.50 \%$ of Primary Schools were included in the high category and $37.50 \%$ of elementary schools with low category. In detail, the details of each category are presented in Table 6.

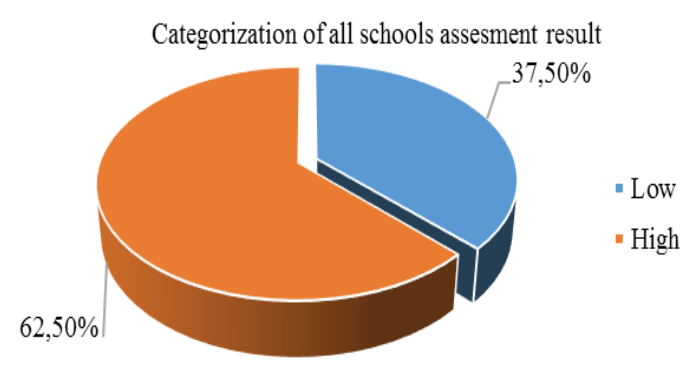

Figure 3. Categorization of all schools assesment result

Based on Table 6 , the results of the teacher achievement showed that 30 elementary schools were included in high category and 18 elementary schools were in low category. 


\section{Discussion}

The assessment of teacher achievement (grade IV, V, and VI teachers) used test instruments. The test was a form of instrument in collecting the data done by written test to grade $\mathrm{IV}, \mathrm{V}$, and VI teachers. The test used by researcher in the form of multiple choice objective test with the scale of politomus, ie each test answer option has a different score. The highest score was 4 (four) and the lowest score was 1 (one).

Professional competency instruments used by teachers in the form of test instruments. The test used by researcher in the form of multiple choice objective test with the scale of politomus, ie each test answer option has a different score. The highest score was 4 (four) and the lowest score was 1 (one). The test questions were composed of 5 indicators contained in the teacher's professional competence. The next five indicators were outlined into sub-indicators to be made into test questions. The number of test items for teachers on professional competence was 40 test points. The validation results of the content of 40 test items on professional competence for teacher respondents showed good results, ie the content coefficient of Aiken's V content most of the test items were greater than 0.8 (> 0.8$)$ with very high validity criteria.

Table 6. Categorization of each school assesmen

\begin{tabular}{cccccccc}
\hline No. & $\begin{array}{c}\text { Elementary } \\
\text { Schools Code }\end{array}$ & Mean & Category & No. & $\begin{array}{c}\text { Elementary } \\
\text { Schools Code }\end{array}$ & Mean & Category \\
\hline 1 & ES 01 & 72.33 & High & 25 & ES 25 & 70.67 & High \\
\hline 2 & ES 02 & 74.67 & High & 26 & ES 26 & 71.00 & High \\
\hline 3 & ES 03 & 73.00 & High & 27 & ES 27 & 68.67 & Low \\
\hline 4 & ES 04 & 71.00 & High & 28 & ES 28 & 67.67 & Low \\
\hline 5 & ES 05 & 64.00 & Low & 29 & ES 29 & 74.33 & High \\
\hline 6 & ES 07 & 61.67 & Low & 30 & ES 30 & 65.67 & Low \\
\hline 7 & ES 08 & 71.33 & High & 31 & ES 31 & 78.00 & High \\
\hline 8 & ES 08 & 69.00 & Low & 32 & ES 32 & 67.33 & Low \\
\hline 9 & ES 09 & 66.33 & Low & 33 & ES 33 & 71.67 & High \\
\hline 10 & ES 10 & 65.33 & Low & 34 & ES 34 & 71.00 & High \\
\hline 11 & ES 11 & 72.00 & High & 35 & ES 35 & 69.67 & Low \\
\hline 12 & ES 12 & 68.33 & Low & 36 & ES 36 & 78.00 & High \\
\hline 13 & ES 13 & 71.67 & High & 37 & ES 37 & 78.00 & High \\
\hline 14 & ES 14 & 71.67 & High & 38 & ES 38 & 70.00 & Low \\
\hline 15 & ES 15 & 72.00 & High & 39 & ES 39 & 73.67 & High \\
\hline 16 & ES 16 & 73.33 & High & 40 & ES 40 & 69.67 & Low \\
\hline 17 & ES 17 & 71.00 & High & 41 & ES 41 & 75.00 & High \\
\hline 18 & ES 18 & 74.00 & High & 42 & ES 42 & 65.33 & Low \\
\hline 19 & ES 19 & 66.33 & Low & 43 & ES 43 & 74.33 & High \\
\hline 20 & ES 20 & 67.33 & Low & 44 & ES 44 & 70.67 & High \\
\hline 21 & ES 21 & 77.67 & High & 45 & ES 45 & 71.33 & High \\
\hline 22 & ES 22 & 73.00 & High & 46 & ES 46 & 73.67 & High \\
\hline 23 & ES 23 & 70.00 & Low & 47 & ES 47 & 72.67 & High \\
\hline 24 & ES 24 & 68.33 & Low & 48 & ES 48 & 74.67 & High \\
\hline & & & & & & & \\
\hline 19 & & & & & \\
\hline
\end{tabular}


The proof of construct validity in professional competency instruments used exploratory factor analysis (EFA) which aims to investigate factors contained in the points of observation. The result of construct validity analysis used EFA on test instrument showed that sample adequacy based on score of Khisquared on Bartlet test was 3109,452 with degrees of freedom 1711 and p-score less than 0.01. In addition, the results of the sample adequacy analysis were also reinforced by Kaiser-Meyer-Olkin Measure of Sampling Adequacy (KMO) of 0.648 greater than 0.5 (> $0.5)$. While the score of loading factor on each test item through EFA has met the specified criteria that was more than $0.4(>0.4)$. So, all the test items were valid.

The headmaster's assessment to high grade teachers (grades IV, V, and VI) used a modified questionnaire by the researcher. Questionnaire is an isntrumen form in collecting the data that is done by giving a set of written statement to the respondents, that is headmasters. Questionnaires were used to assess the performance of school teachers at PGRI Yogyakarta University laboratory. Scale on the scanning of the questionnaire instrument used a Likert scale or summative rating modified used the statement with the highest score of 4 (four) and the lowest score 0 (zero).

Headmasters used the instruments in the form of non-test sheet test questionnaire modified by the researcher. The statement in the questionnaire is an elaboration of the 5 indicators contained in the teacher's professional competence. The 5 indicators of professional competence used to assess teacher achievement, namely: a) Mastering the materials, structure, concepts, and mindset of science, b) Mastering the standard of competence and basic competence, c) Developing learning materials, d) Developing professionalism in a sustainable manner, and e) Utilizing information and communication technology.

The five existing indicators then put into sub-indicators to be made into statements in the questionnaire. Number of respondents questionnaire on professional competence with headmaster's respondents were 15 (fifteen) points statement. The validation of the content of the statement statement on the professional competence for the headmaster's respondents showed good results, ie the content coefficient of Aiken's V content of each questionnaire was greater than $0.8(>0.8)$ with very high validity criteria.
The result of construct validity analysis used EFA on non test instrument showed that sample adequacy was evaluated Chi-Square score (Khi-Square) at Bartlet test 6731,057 with degree of freedom 1128 and p-score less than 0,01 . This indicated that the sample size of 144 used in this factor analysis was sufficient. In addition, the results of the sample adequacy analysis were also reinforced by Kaiser-MeyerOlkin Measure of Sampling Adequacy (KMO) of 0.875 greater than 0.5 .

Based on the exploratory factor analysis, it can be concluded that the loading score of the factors in each test item and the statement on the questionnaire has met the specified criterion that was more than $0.4(>0.4)$. So that all test items and statement on the questionnaire were stated valid and feasible to be used to assess the work performance of school teachers at PGRI University of Yogyakarta. In addition, professional competence instruments can be used and trusted to re-measure on the same object because it had a reliable score and feasibility of high enough or at least had a score of reliability coefficient more than $0,7(>0.7)$. This indicated that the indicators used already have sufficient internal consistency reliability, thorough in measuring and explaining the constants. So that all the instruments used in research assessment of school teachers work performance at PGRI University Yogyakarta laboratory was reliable.

In general, the average achievement of teacher achievement score in terms of professional competence of 71.00. This showed that teacher work performance in terms of professional competence belonged to high category. The lowest raw score achieved on professional competence was 49.00 with a score of 40.00. While the maximum raw score achieved on professional competence was 110.00 with a score of 89.00.

The research involved 11 sub districts in Bantul. Therefore, the researcher also presented the results of the submissions from all the subdistricts involved. The achievement of the average achievement of teachers from each district, namely: Bambanglipuro (73.33), Banguntapan (71.00), Bantul (65.67), Jetis (69.00), Poor (70.18), (71.33), Piyungan $(71,69)$, Sedayu $(71,00)$, and Sewon $(73,08)$. The achievement result showed that there were 4 sub districts included in the low category, namely Bantul, Jetis, Kretek, and Pandak districts.

There were 48 Elementary Schools both public and private used in this research. 
Assessment of all schools was included in the high and low categories. The achievement of each school, there were 18 Elementary Schools with low achievement category. They were: Manding Tengah $(61,67)$, Bantul Timur $(64,00)$, Padokan 1 (65,33), Bandut $(65,33)$, Jolosutro (65,67), Kadipiro 1 (66.33), Sembungan (66.33), Kretek (67.33), Kabregan (67.33), Banyakan (67.67), Brajan (68.33), Gumulan $(68,33)$, Cepokojajar $2(68,67)$, Patalan Baru $(69,00)$, Mojosari $(69,67)$, and Pedes $1(69,67)$.

Based on the description has been known the assesment of teacher's performance result, as a whole, each district and each school. In detail, there were 18 schools from 4 sub-districts belonged to the low category. This, of course, can provide a direct description for the district government, district or school to evaluate the teacher's achievement in the school.

The low of teachers' achievement can be caused by several things, included: in complete school facilities, low motivation from the leader, limited teachers' welfare (considering there are many honorary teachers involved in this research), lack of training related to the field of teacher competence, and the increasing of teacher duties. In line with Mohammad Arifin who revealed one of the job description of the teacher performs additional structural and special tasks. This will certainly take the teacher's time in the process of learning in the classroom.

\section{CLOSING}

Based on the results and discussion in this research, it can be concluded that the test instruments and non-tests used to measure the teachers'achievement at PGRI University Yogyakarta laboratory was appropriate. This was indicated by the validity and reliability of each instrument. Fulfilled the validity and reliability of an instrument proves that the instrument used was appropriate to measure something that should be measured.

Based on the overall achievement result indicated that the teachers' achivement included in the high category. However, when it is viewed from each school, the achievement of the average achievement of teachers showed there were 18 Elementary Schools with low criteria, ie below $70.00(<70.00)$.

The low of teachers'achievement can be caused by several factors such as the increasing of teacher works, the changing of education curriculum at Elementary School level, and the lacking of teacher readiness to the demands of the government that requires all teachers to have
4 teacher competencies. Therefore, there needs to be strengthening for teachers in improving their work prerequisites to become professional teachers. This can be done through training and coaching programs for teachers in each school.

\section{THANKS TO :}

Researcher would like to thank: (1) Rector and academic community of PGRI University Yogyakarta who have provided facilities, moral support, and study permission to the researcher to continue the study of Masters level; (2) Dr. Samsul Hadi, M.Pd., M.T., Dr. Harun, M.Pd and Yulianto, S. Pd., M.Pd., who has reviewed and validated the instruments of this research; (3) Yogyakarta Kesbangpol Service Office, Bappeda of Bantul Regency and Bantul Regency Education Office which has given permission and support to this research; and (4) Headmaster and Elementary School Teachers in Bantul Regency of PGRI Yogyakarta University Laboratory who have been willing to take the time to complete the instruments in this research.

\section{REFERENCES}

Azwar, Saifuddin. 2015. Reliabilitas dan Validitas Edisi 4. Yogjakarta: Pustaka Belajar.

Barnawi \& Mohammad Arifin. 2014. Instrumen Pembinaan, Peningkatan, \& Penilaian Kinerja Guru Profesional. Yogyakarta. ArRuzz Media.

Brown, J. D. 2002. The Cronbach Alpha Reliability Estimate. JALT Testing \& Evaluation SIG Newsletter, 6(1).

Dessler, Gary. 1997. Manajemen Sumber Daya Manusia. Jakarta: PT. Prenhallindo.

Fatimah, S., \& Mahmudah, U. 2017. Pengukuran Efisiensi Kinerja Sekolah Dasar lewat Model Data Envelopment Analysis. Cakrawala Pendidikan, 36 (2): 233-243.

Feldt, L. S. 1980. A Test of The Hypothesis That Cronbach's Alpha Reliability Coefficient is The Same For Two Tests Administered to The Same Sample. Psychometrika, 45(1): 99-105.

Inayatullah, A., \& Jehangir, P. 2005. Teacher's Job Performance: The Role of 
Motivation. Abasyn Journal of Social Science, 5 (2): 78-99.

Johnson, R. L., Penny, J, A., \& Gordon, B. 2009. Assessing Performance: Designing, Scoring, and Validating Perfomance Tasks. New York. The Guilford Press.

Kartowagiran, $\quad$ B. 2008. Validasi Dimensionalitas Perangkat Tes Ujian Akhir Nasional SMP Mata Pelajaran Matematika 2003-2006. Jurnal Penelitian dan Evaluasi Pendidikan, 12 (2):

Kartowagiran, B., Soenarto \& Triyono, B. 2011. Model Evaluasi Kinerja Guru Profesional Pasca Sertifikasi. Yogyakarta: Pascasarjana Universitas Negeri Yogyakarta.

Kartowagiran, B. 2012. Penulisan Butir Soal. Makalah disampaikan pada Pelatihan penulisan dan analisis butir soal bagi Sumber daya PNS DikRekinpeg, di Hotel Kawanua Aerotel, Jakarta.

Kartowagiran, B., \& Maddini, H. 2015. Evaluation Model for Islamic Education Learning in Junior High School and Its Significance to Students' Behaviours. American Journal of Educational Research, 3(8): 990-995.

Mardapi, D. 2012. Pengukuran Penilaian dan Evaluasi Pendidikan. Yogyakarta: Nuha Medika.

Maslach, C., \& Jackson, S. E. (1981). The measurement of experienced burnout. Journal of organizational behavior, 2 (2): 99-113.

Neraca Pendidikan Daerah. (02/01/2017). Diakses pada tanggal 2 Januari 2017, dari http://npd.data.kemdikbud.go.id/file/pdf/ 2016/040000.pdf

Podgursky, M. J., \& Springer, M. G. 2007. Teacher Performance Pay: A Review. Journal of Policy Analysis and Management, 26 (4): 909-949.
Prasetya, T. I. 2012. Meningkatkan Keterampilan Menyusun Instrumen Hasil Belajar Berbasis Modul Interaktif Bagi Guru-Guru IPA SMP N Kota Magelang. Journal of Educational Research and Evaluation, 1(2).

Republik Indonesia. 2005. Undang-Undang RI Nomor 14 Tahun 2005 tentang Guru dan Dosen.

Republik Indonesia. 2008. Peraturan Pemerintah No 74 tahun 2008 tentang Guru.

Retnawati, H. 2014. Teori Respon Butir dan Penerapannya. Yogyakarta: Nuha Medika.

Retnawati, H. 2015. Validitas Reliabilitas dan Karakteristik Butir. Yogyakarta: Parama Publishing.

Supahar, S., Rosana, D., Ramadani, M., \& Dewi, D. K. The Instrument for Assessing the Performance of Science Process Skills Based on Nature of Science (NOS). Cakrawala Pendidikan, 36 (3): 435-445.

Suyadi Prawirosentono. 1999. Kebijakan Kinerja Karyawan. Yogyakarta: BPFE

Virtanen, P., Niemi, H. M., \& Nevgi, A. 2017. Active Learning and Self-Regulation Enhance Student Teachers' Professional Competences. Australian Journal of Teacher Education, 42 (12).

Waksberg, J. 1978. Sampling Methods for Random Digit Dialing. Journal of the American Statistical Association, 73 (361): 40-46.

Yadiannur, M. \& Supahar 2017. Mobile Learning Based Worked Example in Electric Circuit (WEIEC) Application to Improve the High School Students' Electric Circuits Interpretation Ability. International Journal of Environmental and Science Education, 12 (3): 539-558. 